\title{
A Judicial Review of the De Facto Detention of Foreigners in Turkey
}

\author{
Gamze Ovacık ${ }^{1}$
}

\begin{abstract}
The term, de facto detention, refers to instances in which foreigners are held or deprived of their liberty usually with a view to preventing their entry into a country or expelling them from a country, but without implementing a legally prescribed detention regime that satisfies the criteria of the rule of law. The first type of de facto detention occurs when provisions regulating detention are absent or deficient in the legal framework. The second type takes place when domestic law sufficiently regulates detention regimes; however, the law is not duly implemented in practice. This article examines judicial practices in Turkey in both categories of de facto detention, analysing 37 Turkish court decisions with supporting case law from the European Court of Human Rights. Focusing on case law makes it possible both to track deficiencies in administrative practices and to analyse judicial response as a tool for rectifying unlawful administrative practices.
\end{abstract}

Keywords: detention of foreigners, de facto detention, immigration detention, judicial review of detention.

\section{Introduction}

Whereas the situation of the foreigners under de facto detention ${ }^{2}$ might not be identified as detention by national law, in effect they are subject to detention since their liberty is restricted, and this means that they should have access to procedural safeguards and legal remedies related to their detention. De facto detention is, in its essence, a problem of legality rather than necessity, arbitrariness or proportionality, which are all components of the lawfulness of detention. The requirement of legality implies, but is not limited to, compliance with the legal framework. It also indicates satisfaction of the rule of law criteria in the sense that the standards and procedures related to detention should be accessible, precise and foreseeable. Errors of courts in implementing domestic law or other serious breaches of national law such as prolonged detention despite court decisions ordering release have also raised concerns about the rule of law in the judgments of the European Court of Human Rights (“ECtHR”) (Amuur v. France, 1996, para. 50; Dougoz v. Greece, 2001, para. 55; Riad and Idiab v. Belgium, 2008; Costello, 2012, p. 279; Mole \& Meredith, 2010, p. 153).

In the wider meaning of the term, the first type of de facto detention occurs in cases where legal provisions regulating detention are absent or fall short of satisfying the

\footnotetext{
${ }^{1}$ Gamze Ovacık, PhD Researcher, Faculty of Law, Bilkent University, Ankara, Turkey. E-mail: gamze.ovacik@bilkent.edu.tr.

${ }^{2}$ The term, de facto detention, refers to instances in which asylum seekers or irregular migrants are held or deprived of their liberty usually with a view to preventing their entry into a country or expelling them from a country, but without implementing a legally prescribed detention regime that satisfies the criteria of the rule of law.
} 
conditions of the rule of law. Thus, deficiencies in the legal framework make detention a de facto situation rather than a situation that is in accordance with the law. Second, in a narrower sense of the term, de facto detention may also take place when the detention regime is sufficiently regulated by domestic law; however, in concrete situations, the procedural steps outlined in the law are not implemented such as cases of the absence of duly issued administrative decisions ordering detention. This paper analyses judicial practices in Turkey regarding the de facto detention of foreigners in both senses. Since the first type of de facto detention used to arise before the enactment of the latest and current legislative framework, more emphasis will be given to the second type of de facto detention situations, which are still observed in practice. Focusing on case law makes it possible both to track deficiencies in administrative practices and to analyse judicial response as a tool for rectifying unlawful administrative practices.

\section{De Facto Detention in Turkey due to the Lack of Legal Framework}

In 2013, a major legislative reform was carried out regarding asylum and migration issues, and the Law on Foreigners and International Protection (LFIP) was enacted as Turkey's first law in this field. Detention practices in Turkey before the enactment of the LFIP raised serious concerns of legality tantamount to constituting de facto detention in its wider sense. As repeatedly underlined by the ECtHR (Abdolkhani and Karimnia v. Turkey, 2009, paras. 128-135; Alimov v. Turkey, 2016; Babajanov v. Turkey, 2016; Dbouba v. Turkey, 2010; Khaldarov v. Turkey, 2017; Musaev v. Turkey, 2014, paras. 39, 41; Yarashonen v. Turkey, 2014, paras. 48, 50), there was no clear legal framework in Turkey regulating the procedures related to the detention of foreigners. It was also uncommon in general practice to issue detention orders that duly notified foreign detainees and indicated the reasons and legal remedies for their detention.

In a case against Ukraine before the ECtHR, the lack of national legal provisions regulating the procedures for detention prompted the Court to conclude that, beyond the question of whether the administration followed the domestic legal rules, the conformity of those rules with the purposes of the European Convention on Human Rights (ECHR) is also critical (Soldatenko v. Ukraine, 2008, para. 110). In a case against Italy, the ECtHR held the view that the existence of a domestic legal framework is not sufficient and found a violation of the ECHR due to ambiguity and the lack of legal certainty in legislation (Khlaifia and Others v. Italy, 2016, paras. 105-108). In another case, the fact that the national law was unclear, and the fact that the detention, which lasted for several days, was not ordered by a person exercising judicial power authorised by law was judged to cause unlawful detention (Shamsa v. Poland, 2009). The requirement of the quality of law was also expressed by the Court of Justice of the European Union's assessment of objective criteria for risk of absconding (Al Chodor, 2017). In this sense, the two regional courts' legal positions overlap in terms of highlighting the quality of law required of national laws (Platform for International Cooperation on Undocumented Migrants, 2017, p. 24). 
This background demonstrates the importance of the existence and quality of legal frameworks for the detention of foreigners. Without such frameworks, detention practices have no legal basis and thus constitute de facto detention. Due to the lack of a legal framework, there were almost no effective legal remedies in the Turkish judicial system against such detention practices until the LFIP entered into force in 2014. The only remedy, which became available in 2012, was individual application before the Constitutional Court (CC). Very much like the individual application procedure before the ECtHR, in the year 2012, the CC began to accept applications from applicants who can claim violations of rights that are protected by the Turkish Constitution and the ECHR. With respect to the legality of detention practices in Turkey before the LFIP was enacted, the CC followed the ECtHR by basing its decisions concerning Turkey on the ECtHR precedents that were cited above (2013-655, 2016; 2013-1649, 2016; 2013-8735, 2016; 2013-8810, 2016; 2013-9673, 2015; 2014-2841, 2016; 2014-13044, 2015). Thus, Turkish case law is almost identical with that of the ECtHR, finding that, given the lack of legal provisions regulating the detention of foreigners and the lack of duly issued administrative decisions notifying detainees, detention practices constitute a violation of the right to liberty and security.

\section{De Facto Detention in Turkey due to Non-compliance with the Legal Framework}

The LFIP gave the Turkish legal framework adequate provisions for a legal regime of detention of foreigners that satisfies the rule of law criteria. The legislation provides a procedure for the issuance of detention orders, grounds, maximum periods of detention and legal remedies against detention. Thus, in this era, the deficiencies observed correspond to de facto detention in its narrower sense, caused by the administration's failure to follow the procedures related to detention outlined in the law. For the purposes of the ensuing analysis, first, the administrative practices with respect to de facto detention of foreigners will be described and contrasted with the relevant case law. Then, the Turkish case law on the de facto detention of foreigners will be analysed by categorising them as either good or bad practices.

\section{Administrative Practices Concerning the De Facto Detention of Foreigners}

In Turkish detention practices, an ongoing legal issue is that, at times, incidents are observed where foreigners are effectively held in detention, especially in police stations and parts of airport transit zones identified as inadmissible passenger rooms or migration rooms. This has been reported by practising lawyers and NGOs active in the field, and it is also the subject of several court decisions analysed here. As reported from the ground, such de facto detention instances are also problematic because detainees' access to lawyers is frequently hindered. De facto detention also occurs when the administration delays issuing a detention order and thus holds the foreigner without legal basis. First, the case law that guides such as de facto detention will be cited. This will be followed by an analysis of the good and bad practices in the Turkish case law on the de facto detention of foreigners. 
One condition that informs what constitutes de facto detention is the timing of the issuance of detention orders. The legal framework stipulates a time limit of 48 hours for the issuance of detention orders by the migration authority. The 48 hours start with the admission of the individual to the detention facility. If there is no detention facility in the province, the period starts when the police refer the individual's documents to the migration authority. The relevant provision requires this referral to be carried out promptly upon apprehension to prevent de facto detention, and so that foreigners are not held by the police arbitrarily without a detention order. One type of de facto detention of foreigners in Turkey involves extended delays in the transfer of foreigners or the referral of documents by the police to the migration authority, notwithstanding the legal requirement of promptness for such transfers or referrals. The meaning of the concept of promptness has been elaborated in various legal contexts by domestic courts as well as the ECtHR. For instance, Turkish court decisions concerning sale contracts have stipulated that the prompt notification of defects in goods means "without spending much time considering the circumstances" $(E$. 2014/223, K. 2018/28, 2018; E. 2014/883 K. 2019/61, 2019; E. 2017/376, K. 2018/1022, 2018; E. 2017/813 K. 2018/1291, 2018; E. 2017/820, K. 2018/381, 2018; E. 2017/1633 K. 2017/1013, 2017), and in this sense, twelve days is considered to conflict with the requirement of promptness (E. 2013/12545 K. 2013/14522, 2013). Other court decisions underline that the term, promptness, should be assessed based on objective rules of good faith (E. 2017/790 K. $2018 / 406,2018$ ), and the use of this concept is intended to prevent negative consequences that would be caused by delay (E. 2003/4-40 K. 2003/38, 2003). In the context of the deprivation of liberty, the $\mathrm{CC}$ defines the concept of promptness with respect to criminal interrogations and refers to ECtHR case law. The CC explains that, although a specific time limit has not been set for the period of interrogation by the judge, the matter concerns the right to liberty and freedom, which requires minimising the risk of arbitrariness. Accordingly, promptness should be assessed according to the conditions of each case; however, in any case, the essence of the right to liberty and freedom should not be impaired, and the state's obligations to release detainees and to bring them before a judge promptly should never be abolished. In light of this reasoning, the CC found the deprivation of liberty to be unlawful during and after the conclusion of interrogation for fourteen hours and when detention lasts more than three days and twelve hours $(2014 / 14061,2015 ; 2015 / 144,2015)$. In similar cases, the ECtHR has also emphasised that, in order not to weaken procedural safeguards and to protect the essence of the right to personal freedom, the time constraint should not be implemented in a flexible manner, and in certain cases, it found violations due to the deprivation of liberty without a legal basis to be unlawful even if their duration is as little as a few days (Aquilina v. Malta, 1999, para. 48; Brogan and Others v. The United Kingdom, 1988, para. 58; Dikme v. Turkey, 2000, para. 66; Medvedyev and Others v. France, 2010, para. 121).

\section{Turkish Case Law Concerning the De Facto Detention of Foreigners}

Against this background of the problematic administrative practices in Turkey, the analysis of Turkish court decisions will be guided by the principles adopted by the ECtHR 
regarding de facto detention. The ECtHR assesses deprivation of liberty according to the concrete situation on a case-by-case basis and regards to all circumstances cumulatively, including the type of measure, its period, its effects and how it is applied (Bloomfield et al., 2015, p. 32). The ECtHR has repeatedly found that holding asylum seekers in the transit zones of airports constitutes detention (Platform for International Cooperation on Undocumented Migrants, 2017, p. 9), and that doing so is unlawful (Amuur v. France, 1996; Riad and Idiab v. Belgium, 2008). In both cases, the ECtHR did not accept the governments' argument that the individuals were not deprived of liberty because they were free to take a flight out of the country and leave. In Amuur v. France, the fact that the individuals were subject to an unclear legal regime without legal remedies regarding the conditions or duration of detention and the fact that they were unable to access any kind of assistance led the Court to find that there was a violation of the requirement for the deprivation of liberty to be in accordance with a procedure prescribed by law. In more recent similar cases as well (Ilias and Ahmed v. Hungary, 2017; Z.A. and Others v. Russia, 2017), the ECtHR decided that confining individuals in the international zone of an airport for lengthy periods without legal basis constitutes a deprivation of liberty despite their freedom to leave voluntarily since this option does not rule out the risk of unlawful deprivation of liberty. The Court did not regard the government's claim that the transit zone was not within the territory of the nation. The government failed to satisfy the requirement of lawfulness due to the lack of preciseness and foreseeability of national law and the absence of a duly issued detention order to the individuals.

In some cases, Turkish judges have emphasised that situations that constitute detention in effect are unlawful. In one case where the applicant was held in a detention facility in İstanbul, the administration failed to submit a removal order to the Court and issue a detention order to the applicant. The judge ruled that no one can be deprived of their liberty without a duly issued detention order and thus ordered the release of the individual (2014/3351 D. Işs, 2015). In case of an applicant being held at the Istanbul Sabiha Gökçen airport, the judge ordered release because no detention order was issued despite the expiration of the 48-hour time limit prescribed by the legislation $\left(2015 / 890 \mathrm{D}\right.$. $\left.\dot{I}_{s}, 2015\right)$. In another case, the applicant was held in detention for six months based on a duly issued detention order; however, no decision was made to extend detention beyond this period despite ongoing detention. The Court considered this de facto detention and based its acceptance of the complaint on the unlawfulness of the measure $\left(2018 / 2756\right.$ D. $\dot{I}_{s}$, 2018). When these judgments are analysed, it is seen that the judges have taken into account all the facts surrounding the cases and adopted the principles outlined in the ECtHR case law referred above. It is desirable that decisions like these become standard practice and are taken as an example by other courts as well.

Despite these good practices, there are also some Turkish court decisions where judges failed to recognise the unlawfulness of de facto detention. For instance, in one case, although the Court annulled a detention order due to lack of reasons for extending it, it did 
not address the fact that the decision to extend detention was issued four days after the expiration of the initial detention period, as a result of which, the individual was subjected to detention without a legal basis for those four days $\left(2016 / 2622 \mathrm{D}\right.$. $\left.\dot{I}_{S}, 2016\right)$. As can be remembered from the judgments of the ECtHR and $\mathrm{CC}$, the shortness of the period of de facto administrative detention is not decisive and periods as short as in this case were several times found unlawful. In another decision, the judge paradoxically rejected the complaint of the applicant by claiming that being held under de facto detention was to the benefit of the applicant. The Pakistani national came to Turkey without a valid visa and was refused entry at the airport where he submitted an asylum application. After his application was rejected, he lodged a judicial appeal, and he was held in the inadmissible passenger room of the airport without a detention order awaiting the outcome of his appeal. When assessing the lawfulness of deprivation of liberty, the judge inaccurately stated that the applicant would face a removal order if released, whereas the applicant was allowed by legislation to stay in the country until the asylum rejection was made final upon appeal. So his complaint was rejected in order to enable him to avoid a removal order because he clearly wanted to stay in Turkey (2014/2738 D. Işs, 2014). This case emerges an example of lack of a full understanding of the legal framework, and as a result, the judge errs in his conclusion. In another case with very similar circumstances, the complainant was again being held in the inadmissible passenger room of the airport, pending the outcome of his appeal against the inadmissibility of his asylum application. Despite the ECtHR's consistent case law on the detention of foreigners in airports cited above, the Court reached a decision very similar to the line of reasoning of the governments in those cases. The request of the annulment of detention was rejected because no detention order was issued, and the individual was staying at the airport voluntarily, free to go back to his country of origin or somewhere else $\left(2015 / 3510 \mathrm{D}\right.$. $\dot{I}_{S}$, 2015). The lawyers that I contacted to obtain court decisions within the scope of this study reported that this kind of judgments are prevalent among the judiciary. This shows that more often than not, the judges should be reminded of the relevant ECtHR case law in order to transform the judicial practice.

Judges also sometimes reject complaints when applicants are held at airports (2019/1655 D. $\left.\dot{I}_{S ̧,}, 2019\right)$ or in police stations $\left(2017 / 982\right.$ D. Işs, 2017; 2017/2289 D. $\left.\dot{I}_{S ̧}, 2017\right)$ without any administrative decision to do so. It is worth noting that the incidents in police stations concerned a single Syrian woman in one case (2017/982 D. İş, 2017) and an Afghan family with three minor children in the other $\left(2017 / 2289\right.$ D. $\dot{I}_{S ̧}, 2017 ; 2017 / 3174$ D. $\left.\dot{I}_{S}, 2017\right)$. In all three of these cases, the judges asserted that the request for annulment of detention was unacceptable because no detention order had been issued. The problem with these decisions is that the lack of administrative detention order which is in fact the very source of unlawfulness, became in the Court's argumentation, the reason of lawfulness. In the case of the Afghan family, a detention order was later issued to the parents, and the entire family was transferred to a removal centre. In rejecting the complaint against the detention of the entire family, the judge, rather than finding their de facto detention unlawful, asserted that the children were not in detention, but were staying with their parents $\left(2017 / 2843 \mathrm{D}\right.$. $\dot{I}_{S}$, 
2017). Compared to the Court of first instance's ruling that the children were free to leave with their parents' permission, the approach adopted by the Czech Supreme Administrative Court is inspiring. That Court took into account the ECHR and the United Nations Convention on the Rights of the Child and concluded that minors cannot leave their parents in detention because they have nowhere else to go, so the measure constitutes detention and is unlawful (Czech Republic Supreme Administrative Court, 17 June 2015, 1 Azs 39/2015-56 | European Database of Asylum Law, n.d.).

Another case of de facto deprivation of liberty relates to an applicant who was held in the police station without any detention orders. The Court found the measure lawful relying on the presence of a criminal investigation file with respect to the applicant (2018/4828 D.

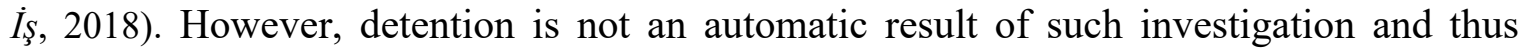
requires a separate detention order, be it for criminal detention or detention for removal purposes. The Court here disregarded the distinction between criminal and administrative detention leading to confusion in the applicable legal framework.

In the cases analysed above, whereas the lack of an administrative order should be the very basis of the unlawfulness of the implemented measure, the judges relied on this administrative discrepancy in order to refuse to conduct legal reviews of detention, limiting their jurisdiction to the review of detention orders. This position of rejecting the legal review of the de facto detention of foreigners is problematic because it fails to uphold the right to personal freedom as provided in the Constitution and ECHR, and because the applicants do not have any other legal remedy against the de facto deprivation of their liberty.

Finally, a court decision rejecting a complaint against de facto detention at the airport based on the failure of the applicant's lawyer to submit a power of attorney should be mentioned $\left(2017 / 1045\right.$ D. $\left.\dot{I}_{S}, 2017\right)$. In fact, the de facto detention that is the very subject of the complaint was the cause of this procedural irregularity since the administration did not allow the lawyer to visit the detainee. Reportedly, lawyers try to overcome such situations by obtaining interim measure decisions from the $\mathrm{CC}$ to prevent removal, for instance, in a case that involves a Syrian applicant who was held in Istanbul Atatürk Airport's inadmissible passenger room $(2018 / 32122,2018)$.

Two individual applications examined by the CC included instances of non-voluntary stays at reception and accommodation centres allocated for asylum seekers. Although not referred to as "detention" by the authorities or described as such in the law, their situation in effect constituted deprivation of liberty since they were confined in specific locations. In one case, the Hatay 1. Criminal Court of Peace rejected the complaint against detention with a decision dated 11 June 2014. The decision was based on the reasoning that the law specifies no complaint mechanisms concerning stays in reception and accommodation centres. According to this perspective, regardless of its characterisation by the administration, a non-voluntary stay in a closed facility is not considered detention (2014- 
19436, 2018, paras. 19-21). In the other case, after the applicant's detention was terminated, the applicant was transferred to the reception and accommodation center in Adana. When the complaint was filed, the criminal Court of peace refused to conduct a legal review of the situation based on the absence of detention (2014/242 D. $\left.\dot{I}_{S}, 2014\right)$ and the judge's lack of authority $\left(2014 / 1675\right.$ D. $\left.\dot{I}_{s}, 2014\right)$. Here again, lack of detention order itself became the Court's basis of lawfulness whereas, in fact, it is the reason for unlawfulness. The applicant was finally released after filing a third complaint before a criminal court of peace $\left(2014 / 431 \mathrm{D}\right.$. $\left.\dot{I}_{S}, 2014\right)$. The CC criticised the first two court decisions for causing the unlawful deprivation of liberty because of the lack of legal review based on the non-characterisation of the measure as detention (2014-15824, 2016, para. 148).

\section{Conclusion}

This paper describes two types of de facto detention. The first type occurs when legal provisions regulating detention are absent or do not satisfy the conditions of quality of law. The second type of de facto detention takes place when domestic law sufficiently regulates the conditions of detention, but in practice, the administrative steps required by the law are not duly implemented. Both types render detention unlawful.

This analysis demonstrates that the first type of de facto detention, based on the lack of an adequate legal framework, was observed in Turkey before 2013 when the legislation on asylum and migration was first enacted. Before 2013, there was no clear legal framework in Turkey regulating the procedures related to the detention of foreigners. It was also not common in general practice to issue detention orders to foreigners, including the reasons and legal remedies for detention. The case law of the ECtHR and the Turkish Constitutional Court have severely criticised this negligence.

In 2013, the legal framework regulating detention and other issues related to foreigners was adopted. This was a groundbreaking development in the Turkish legal realm. Since then, the deficiencies observed in Turkish practice have corresponded to the second type of de facto detention, caused by the administration's failure to follow the procedures outlined in the law. Incidents subject to court decisions include extended detention in places such as police stations and airports without implementing the legal procedures for detention. Judicial practices in these cases have varied widely, with good examples of the courts ruling that situations which constitute detention in effect are unlawful, and bad practices where Turkish judges have failed to recognise the unlawfulness of de facto detention.

This analysis of cases related to de facto detention demonstrates the lack of uniformity in Turkish judicial practices. This is partly due to the fact that the legal framework in Turkey concerning the detention of foreigners is still new, and the case law is still emerging. Considering the clear and established ECtHR case law on de facto detention, consistently good practices are highly desirable in the Turkish judiciary.

Finally, to have an overview from a wider and a theoretical lens, the judicial dynamics described herein can be analysed through the application of neo-functionalist theories in 
terms of the process of Turkish integration to the EU system of migration management. Neo-functionalism emerges as a theory of regional integration which was especially influential for theorising about the inception phase of the EU integration over the 1950s and 1960s. Among the several mechanisms that are thought within neo-functional theories that advance regional integration, the spillover effect is significant for adaptation to our purposes here. The notion of spillover effect, which denotes an economic conceptualisation, means in basic terms that integration between states in one area is likely to trigger integration in other areas as well. This is due to the purpose of full realisation of the benefits of integration in the first area. The spillover effect is a neo-functionalist take on explaining the driving force behind integration. (Niemann \& Schmitter, 2009, pp. 50-52) It is possible to have a fresh look at Turkish judiciary's attitude to de facto administrative detention, building on the neo-functionalist notion of spillover effect. Within the fields comprising migration and asylum policies, management of the administrative detention merely constitutes one. Taken within the broader policy area, management of mixed migration flows affecting Turkey as well as EU member states alike, require coherence in policy areas such as border management, fight against human trafficking and irregular migration, asylum as well as regular migration through issuance of visas or residence permits. The inter-linkage between these policy areas signify that one measure taken within one area affects dynamics within another area.

Moreover, beyond the link between policy areas, due to geopolitical positioning, the management of the mentioned policy areas are highly inter-dependent between Turkey and EU member states. Thus, the spillover effect is observed through the process of management of policy areas related to migration and asylum between Turkey and EU member states. This is already visible in the adoption of the Turkish legal framework very much based on EU acquis in various areas of migration and asylum. However, the acts of the spillover effect are beyond such norm diffusion. In this vein, by pointing out the similarities between the judgments of Turkish and European judges, one of the purposes of this paper was to show through the specific example of de facto administrative detention that judiciary is an area that has the potential of harmonisation between Turkey and EU member states in consideration of the spillover effect in migration and asylum. It should also be noted that due to the impact of the said dynamic, the harmonisation efforts in several fields of migration and asylum between Turkey and EU member states also trigger harmonisation in other fields through spillover effect and thus the interaction with respect to case law on de facto administrative detention is both the result and reason for similarities in case law on other fields of migration and asylum. 
152 A Judicial Review of the De Facto Detention of Foreigners in Turkey

\section{References}

2013-655, F.A. and M.A. (Constitutional Court 20 January, 2016).

2013-1649, A.V. and Others (Constitutional Court 20 January, 2016).

2013-8735, F.K. and Others (Constitutional Court 17 February, 2016).

2013-8810, T.T. (Constitutional Court 18 February, 2016).

2013-9673, Rida Boudraa (Constitutional Court 21 January, 2015).

2014/242 D. İş, (Yalova 3. Criminal Court of Peace 18 June, 2014).

2014/431 D. İss, (Adana 1. Criminal Judge of Peace 31 July, 2014).

2014/1675 D. İs, (Adana (Closed) Criminal Court of Peace 27 June, 2014).

2014/2738 D. İş, (Bakırköy 3. Criminal Judge of Peace December 10, 2014).

2014-2841, A.S. (Constitutional Court 9 June, 2016).

2014/3351 D. İş, (İstanbul 3. Criminal Judge of Peace 30 January, 2015).

2014-13044, K.A. (Constitutional Court 11 November, 2015).

2014/14061, (Constitutional Court 8 April, 2015). https://www.lexpera.com.tr/ictihat/anayasa-mahkemesi/ genel-kurul-k-2014-14061-t-8-4-2015

2014-15824, I.S. and Others (Constitutional Court 22 September, 2016).

2014-19436, M.A. (Constitutional Court 26 December, 2018).

2015/144, (Constitutional Court 14 July, 2015). https://www.lexpera.com.tr/ictihat/anayasa-mahkemesi/ genel-kurul-k-2015-144-t-14-7-2015

2015/890 D. İş, (İstanbul Anadolu 10. Criminal Judge of Peace 21 April, 2015).

2015/3510 D. İs, (Bakırköy 2. Criminal Judge of Peace June 29, 2015).

2016/2622 D. İş, (Antalya 2. Criminal Judge of Peace 19 August, 2016).

2017/982 D. İş, (İstanbul 2. Criminal Judge of Peace 13 March, 2017).

2017/1045 D. İş, (İstanbul 2. Criminal Judge of Peace 13 March, 2017).

2017/2289 D. İs, (İstanbul 1. Criminal Judge of Peace 7 June, 2017).

2017/2843 D. İş, (İstanbul 2. Criminal Judge of Peace 8 June, 2017).

2017/3174 D. İs, (İstanbul 2. Criminal Judge of Peace 21 June, 2017).

2018/2756 D. İş, (Edirne 2. Criminal Judge of Peace 3 July, 2018).

2018/4828 D. İş, (İstanbul 12. Criminal Judge of Peace 4 October, 2018).

2018/32122, (Constitutional Court 14 November, 2018).

2019/1655 D. İş, (İstanbul 2. Criminal Judge of Peace 11 March, 2019).

Abdolkhani and Karimnia v. Turkey, No. 30471/08 (ECtHR 22 September, 2009).

Al Chodor, C-528/15 (CJEU March 15, 2017).

Alimov v. Turkey, No. 14344/13 (ECtHR 6 September, 2016).

Amuur v. France, No. 19776/92 (ECtHR June 25, 1996).

Aquilina v. Malta, No. 25642/94 (ECtHR April 26, 1999).

Babajanov v. Turkey, No. 49867/08 (ECtHR 10 May, 2016).

Bloomfield, A., Tsourdi, E. (Lilian), \& Pétin, J. (2015). Alternatives to Immigration and Asylum Detention in the $E U$.

Brogan and Others v. The United Kingdom, 1209/84; 11234/84; 11266/84; 11386/85 (ECtHR 29 November, 1988).

Costello. (2012). Human Rights and the Elusive Universal Subject: Immigration Detention Under International Human Rights and EU Law. Indiana Journal of Global Legal Studies, 19(1), 257. https://doi.org/10.2979/ indjglolegstu.19.1.257

Czech Republic-Supreme Administrative Court, 17 June 2015, 1 Azs 39/2015-56 | European Database of Asylum Law. (n.d.). Retrieved 16 May, 2019, from https://www.asylumlawdatabase.eu/en/caselaw/czech-republic-supreme-administrative-court-17-june-2015-1-azs-392015-56\#content

Dbouba v. Turkey, No. 15916/09 (ECtHR 13 July, 2010).

Dikme v. Turkey, No. 20869/92 (ECtHR July 11, 2000). 
Dougoz v. Greece, No. 40907/98 (ECtHR 6 March, 2001).

E. 2003/4-40 K. 2003/38, (Turkish Court of Cassation General Assembly of Criminal Chambers 11 March, 2003). http://www.kazanci.com/kho2/ibb/files/dsp.php?fn=cgk-2003-4-40.htm\&kw='derhal $+\mathrm{s} \% \mathrm{C} 3 \%$ B6zc\%C3\%BC\%C4\%9F\%C3\%BC'\#fm

E. 2013/12545 K. 2013/14522, (Turkish Court of Cassation 19. Civil Chamber 23 September, 2013). http:/www. kazanci.com/kho2/ibb/files/dsp.php?fn=19hd-2013-12545.htm\&kw='derhal+kavram\% $\mathrm{C} 4 \% \mathrm{~B} 1{ }^{\prime} \# \mathrm{fm}$

E. 2014/223, K. 2018/28, (Bakırköy 10. Commercial Court 16 January, 2018). https://www.lexpera.com.tr/ ictihat/adli-yargi-ilk-derece-mahkemeleri/bakirkoy-10-asliye-ticaret-mahkemesi-e-2014-223-k-2018-28t-16-1-2018

E. 2014/883 K. 2019/61, (İstanbul 5. Commercial Court 29 January, 2019). https://www.lexpera.com. tr/ictihat/adli-yargi-ilk-derece-mahkemeleri/istanbul-5-asliye-ticaret-mahkemesi-e-2014-883-k-2019-61$\mathrm{t}-26-2-2019$

E. 2017/376, K. 2018/1022, (Bakırköy 4. Commercial Court November 5, 2018). https://www.lexpera. com.tr/ictihat/adli-yargi-ilk-derece-mahkemeleri/bakirkoy-4-asliye-ticaret-mahkemesi-e-2017-376-k2018-1022-t-5-11-2018

E. 2017/790 K. 2018/406, (İstanbul Regional Court 12. Civil Chamber April 5, 2018). https://www.lexpera. com.tr/ictihat/bolge-adliye-mahkemesi/istanbul-bam12-hd-e-2017-790-k-2018-406-t-5-4-2018-1

E. 2017/813 K. 2018/1291, (İstanbul Regional Court 22. Civil Chamber July 16, 2018). https://www.lexpera. com.tr/ictihat/bolge-adliye-mahkemesi/ankara-bam22-hd-e-2017-813-k-2018-1291-t-16-7-2018

E. 2017/820, K. 2018/381, (İstanbul 16. Commercial Court 25 April, 2018). https://www.lexpera. com.tr/ictihat/adli-yargi-ilk-derece-mahkemeleri/istanbul-16-asliye-ticaret-mahkemesi-e-2017-820-k2018-381-t-25-4-2018

E. 2017/1633 K. 2017/1013, (Turkish Court of Cassation General Assembly of Civil Chambers 24 May, 2017). https://www.lexpera.com.tr/ictihat/yargitay/hukuk-genel-kurulu-e-2017-1633-k-2017-1013-t-245-2017

Ilias and Ahmed v. Hungary, No. 47287/15 (ECtHR 14 March, 2017).

Khaldarov v. Turkey, No. 14334/13 (ECtHR 5 September, 2017).

Khlaifia and Others v. Italy, No. 16483/12 (ECtHR 15 December, 2016).

Medvedyev and Others v. France, No. 3394/03 (ECtHR 29 March, 2010).

Mole, N., \& Meredith, C. (2010). Asylum and the European Convention on Human Rights. Council of Europe Publishing.

Musaev v. Turkey, No. 72754/11 (ECtHR 21 October, 2014).

Niemann, A., \& Schmitter, P. C. (2009). Neo-Functionalism. In A. Wiener \& T. Diez, Theories of European Integration (2nd ed.). Oxford University Press.

Platform for International Cooperation on Undocumented Migrants. (2017). Defending Migrants' Rights in the Context of Detention and Deportation Synthesis Report.

Riad and Idiab v. Belgium, 29787/03 and 29810/03 (ECtHR 24 April, 2008).

Shamsa v. Poland, No. 45355/99 (ECtHR 27 November, 2009).

Soldatenko v. Ukraine, No. 2440/07 (ECtHR October 23, 2008).

Yarashonen v. Turkey, No. 72710/11 (ECtHR 24 June, 2014).

Z.A. and Others v. Russia, 61411/15, 61420/15, 61427/15, 3028/16 (ECtHR 28 March, 2017). 